\title{
BAFFIN BAY CONTINENTAL SHELF CLAY MINERALOGY
}

\author{
RANALD W. BOYD and DAVID J.W. PIPER \\ Departments of Geology and Oceanography, Dalhousie University, \\ Halifax, Nova Scotia, Canada
}

\section{INTRODUCTION}

Little is known about either the sources or mode of deposition of surficial sediment on the continental shelves in Baffin Bay. Interpretation of depositional processes is discussed by Pelletier et al 1974, and Marlowe (1968), Grant (1971) and Baker and Friedman (1973) have identified source areas of the coarser sediment fraction. Surficial sediments are in part ice-rafted, and are partly derived by weathering or reworking of Pleistocene till. River sediment is probably mostly trapped in fjords.

We have used $x$-ray diffraction analysis of the carbonate-free fraction $(<50 \mu)$ of about 50 sediment samples to try to distinguish sources of fine sediment. A preliminary interpretation of the first 14 of these analyses is given by Piper and slatt (1976) who describe the methods used, which in general follow those of Biscaye (1965). About 35 of the samples are surficial, the remainder are resedimented material (mostly mudflows) from the central basin of the Bay, believed derived from shelf sediments during Pleistocene glaciation.

\section{RESULTS}

Almost all samples contain significant amounts of illite-mica, chlorite, montmorillonite, kaolinite, quartz and feldspars in the $<2 \mu$ fraction. The percentage of montmorillonite and kaolinite in surficial samples, expressed as a percentage of the total clay minerals, is shown in Figure 1 . Chlorite content usually lies between 10 and 20\%. Typical $x$-ray diffractograms of of glycolated samples are shown in Figure 2.

Montmorillonite is commoner in the northern part of the Bay. Low kaolinite contents are found close to the Greenland coast, and in the southern part of the Bay. Illite-rich samples, with high feldspary. quartz ratios, are commonest on the Greenland Shelf, especially close to land. Low feldspar/quartz ratios, and higher percentages of montmorillonite and kaolinite, are found close to shore in areas of known Mesozoic-Cenozoic sediments at Pond Inlet and around the eastern end of Lancaster Sound. Chlorite is most abundant in the northwestern part of the bay. Clay mineralogy appears independent of both coarsefraction petrology and microfossil abundance (Fig. 3).

\section{DISCUSSION}

Most sediments can be interpreted as representing mixtures from four main sources:

(1) A clastic sedimentary source, with low feldspar/ quartz ratios and little or no montmorillonite. Illite, chlorite and kaolinite are all present. Sample Cl70 (Fig. 2), representing this source, is red in colour. This source consists of sediments including red beds.

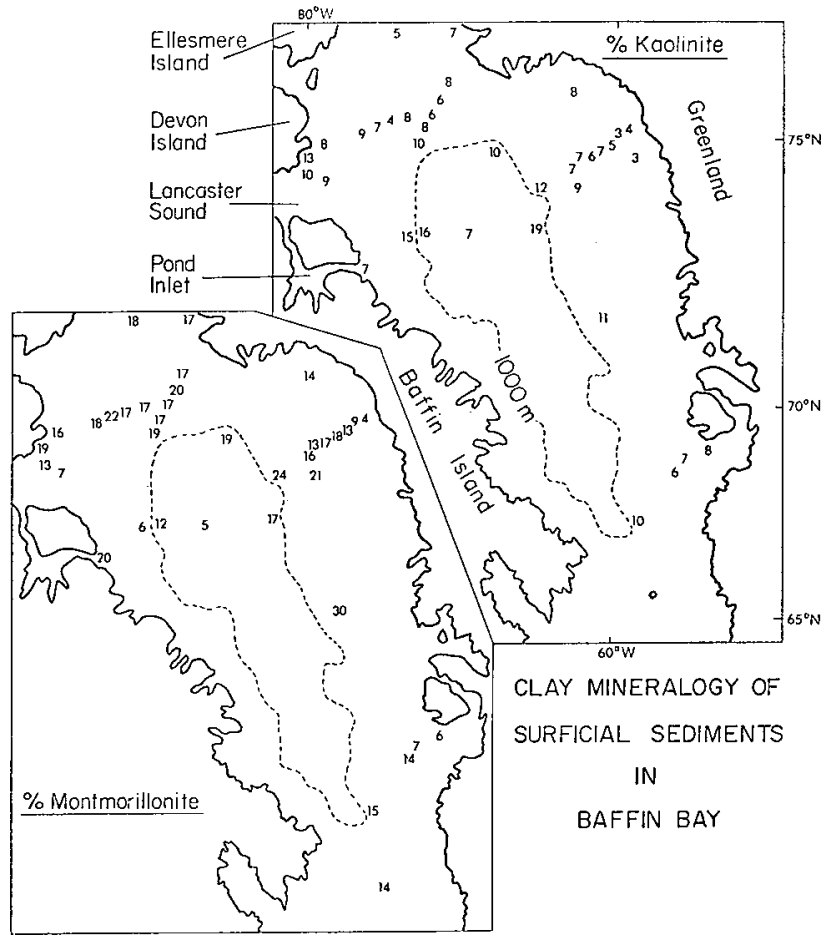

FIG. I Percentage of montmorillonite and kaolinite in surficial sediments from Baffin Bay.

(2) A source rich in carbonate, which is found throughout the whole range of grain sizes. This is associated with low feldspar/quartz ratios, an overall low quartz content, and some montmorillonite and illite. Sample 2A (Fig. 2) is dominated by this source material. The Paleozoic limestones and shales of Devon and Ellesmere Islands constitute this source.

(3) A source with abundant illite/mica, a high feldspar to quartz ratio, and crystalline rock fragments abundant in the sand fraction. Sample 194 (Fig. 2) is a good example of a sediment dominated by this source material. The Precambrian areas of Greenland and Baffin Island constitute this source.

(4) A fourth source is inferred, although it is not well represented by any single sample. It is a clastic sedimentary source rich in montmorillonite and probably also chlorite. In sample 52 (Fig. 2), it is mixed with material from source (1), and in 12 (Fig. 2) with material from source (3). 


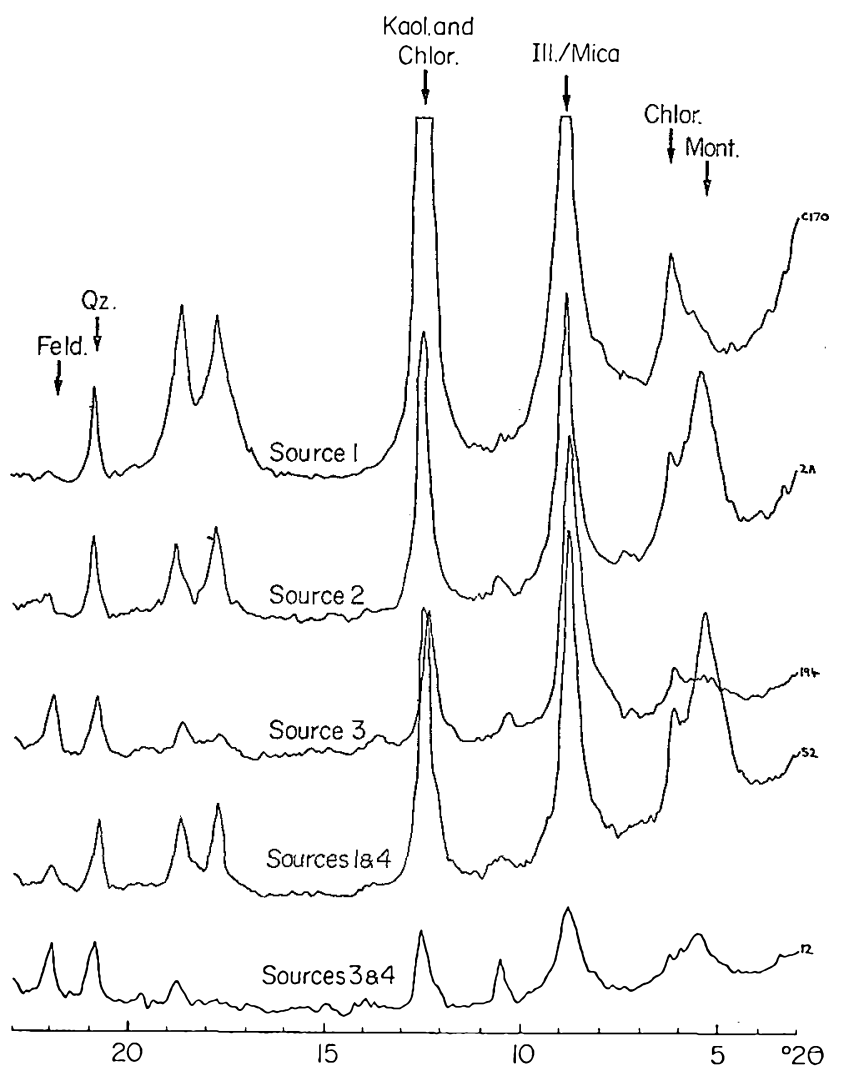

FIG. 2 X-ray diffractograms of selected samples of the gly. colated < $2 \mu$ fraction from Baffin Bay, illustrating inferred source areas.

FIG. 3 Ternary plot showing relationship between clay mineralogy and sand-fraction petrology.

\section{Sand fraction petrology Illite/Mica andChlorite}

- $>25 \%$ carbonate rock fragments

$\Delta>25 \%$ other rock fragments

- $>25 \%$ foraminifera

- others (mostly quartz)

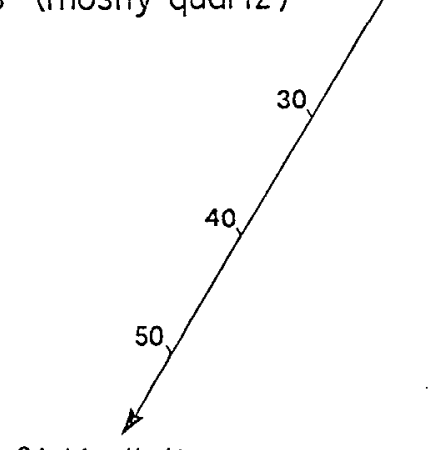

$\%$ Kaolinite
The lack of correlation between clay mineralogy and both microfossils and coarse-fraction petrology suggests that contemporary transport of sediment plays a minor role in determining clay mineralogy. Local reworking of till is probably the dominant process. Sediments from sources (2) and (3) were probably transported to the continental shelves by grounded ice (nearshore) and icebergs! sediments from sources (1) and (4), which are presumably submerged Cenozoic or Mesozoic continental-shelf strata, were probably eroded by the grounded ice that eroded the glacial valleys found on the shelves.

\section{ACKNOWLEDGEMENTS}

We thank the Atlantic Geoscience Centre of the Bedford Institute of Oceanography, Dartmouth, Nova Scotia, for releasing samples, and W.S. Mitchell for assistance with X-ray diffraction. This work was supported by National Research Council of Canada operating grant to Piper.

\section{REFERENCES}

BAKER, S.R. and FRIEDMAN, G.M., 1973, Sedimentation in an Arctic marine environment: Baffin Bay between Greenland and the Canadian Arctic Archipelago. Geol. Surv. Canada Paper 71-23, pp. $471-491$.

BISCAYE, P.E., 1965, Mineralogy and sedimentation of recent deep sea clays in the Atlantic Ocean and adjacent seas and oceans. Geol. Soc. Amer. Bull., 76, pp. 803-832.

GRANT, A.C., 1971, Distributional trends in the Recent marine sediments of Baffin Bay, Maritime Sediments, 7, pp. 41-63.

MARLOWE, J.I., 1968, Unconsolidated marine sediments in Baffin Bay. J. sed. Pet., 38, pp. 1065-1078.

PELLETIER, B.R., ROSS, D.I., KEEN, C.E. and KEEN, M.J., 1974, Geology and Geophysics of Baffin Bay. Geol. Surv. Canada Paper 74-30, pp. 247-258.

PIPER, D.J.W., and SLATT, R.M., 1976, Late Quaternary clay mineral distribution on the eastern continental margin of Canada. Geol. Soc., Amer. Bull., 87. 